\title{
STRESS IN NURSES WORKING IN INTENSIVE CARE UNITS ${ }^{1}$
}

\author{
Ana Maria Cavalheiro ${ }^{2}$ \\ Denis Faria Moura Junior ${ }^{3}$ \\ Antonio Carlos Lopes ${ }^{4}$
}

Cavalheiro AM, Moura Junior DF, Lopes AC. Stress in nurses working in intensive care units. Rev Latino-am Enfermagem 2008 janeiro-fevereiro; 16(1):29-35.

The present study aimed to identify the presence of stress in nurses working in intensive care units, the stressing agents and symptoms associated to the nurses' perceptions of stress, and to assess the correlation between the occurrence of stress, sources of stress, and symptoms shown by the nurses. Seventy-five nurses took part in the study. The data were collected from questionnaires, analyzed with the Pearson correlation coefficients, and adjusted by general linear models. The study showed the presence of stress related to work dissatisfaction, activities regarded as critical situations in intensive care units, symptoms related to cardiovascular, digestive and musculoskeletal disorders. The conclusion is that stress is present in nurses' activities in intensive care units, related to characteristics of the health area itself, causing dissatisfaction and stress-related symptoms.

DESCRIPTORS: nursing; work; stress

\section{EL ESTRÉS DE LOS ENFERMEROS QUE ACTÚAN EN UNA UNIDAD DE TERAPIA INTENSIVA}

El presente estudio tuvo como objetivos: identificar la presencia de estrés en enfermeros que trabajan en unidades de terapia intensiva; identificar a los agentes estresantes y a los síntomas asociados al estrés, según la percepción del enfermero; $y$, evaluar la correlación entre la presencia del estrés, las fuentes del estrés y los síntomas presentados por los enfermeros. Setenta y cinco enfermeros participaron del estudio. Los datos fueron recolectados por medio de cuestionarios. El análisis fue realizado utilizando los coeficientes de correlación de Pearson y ajustando con modelos lineales generalizados. El estudio mostró la presencia de estrés correlacionado a: la insatisfacción en el trabajo; a las actividades consideradas como situaciones críticas en unidad de terapia intensiva; a los síntomas relacionados con alteraciones cardiovasculares; al aparato digestivo y a los músculos del esqueleto. La conclusión del estudio es que el estrés está presente en la actividad del enfermero en las unidades de terapia intensiva y está correlacionado a factores pertinentes al sector, generando insatisfacción con la profesión y presentando síntomas correlacionados al estrés.

DESCRIPTORES: enfermería; trabajo; estrés

\section{ESTRESSE DE ENFERMEIROS COM ATUAÇÃO EM UNIDADE DE TERAPIA INTENSIVA}

O presente estudo teve como objetivos identificar a presença de estresse em enfermeiros que trabalham em unidades de terapia intensiva, identificar os agentes estressores e sintomas associados à percepção do enfermeiro ao estresse e avaliar a correlação entre a presença de estresse, fontes de estresse e sintomas apresentados pelos enfermeiros. Setenta e cinco enfermeiros participaram do estudo. Os dados foram obtidos por questionário. A analise foi realizada através do uso de coeficientes de correlação de Pearson e ajustados modelos lineares generalizados. O estudo mostrou a presença de estresse correlacionado à insatisfação com o trabalho, atividades consideradas como situações críticas em unidade de terapia intensiva, os sintomas relacionados às alterações cardiovasculares, aparelho digestivo e músculo-esquelético. A compreensão final é que o estresse está presente na atividade do enfermeiro em unidade de terapia intensiva, correlacionado com fatores pertinentes ao setor, gerando insatisfação com a profissão e sintomas ligados ao estresse.

\section{DESCRITORES: enfermagem; trabalho; estresse}

\footnotetext{
${ }^{1}$ Paper extracted from Master's Thesis; ${ }^{2}$ RN, Hospital Israelita Albert Einstein, Doctoral student at São Paulo Federal University, Brazil, e-mail: anamcavalheiro@yahoo.com.br; ${ }^{3}$ Co-Advisor, RN, Hospital Israelita Albert Einstein;Brasil; ${ }^{4}$ Advisor, Full Professor, São Paulo Federal University, Brazil, email: aclopes@climed.epm.br
} 


\section{INTRODUCTION}

The ever-growing changes that happened in the globalization process have defined the way of living and other patterns of health-sickness, also causing a strong influence in the working structure ${ }^{(1-5)}$.

These new health-sickness patterns, in a global context, have brought about concerns with the stress factor, earning a distinguished place in research about falling ill at the workplace ${ }^{(1)}$.

Stress was first defined in the 1950s, with the description of the general adaptation syndrome as a state where several systems of the organism move away from their normal resting conditions due to a non-specific agent, which causes stress through the activation of a chain of reactions, due to the release of catecholamines and glucocorticoids ${ }^{(2)}$.

Although the organism's response to stress is well understood, it was necessary to understand the role of the individual, with the subject's assessment of the stress agent being a primordial part of the stress triggering process ${ }^{(3)}$.

Several investigations about the worker's health define stress as the result of emotional weariness, lack of control in highly-demanding working situations, feelings of exertion, fatigue and changes in health ${ }^{(4-9)}$.

Occupational stress in the healthcare area is associated to specific situations, such as problems with co-workers, ambiguity and function conflicts, the work-home double shift, pressure from superiors according to the individual's perception and changes undergone within the context of the occupation. These situations may be important sources of stress ${ }^{(10-13)}$

Among these, the nurse was not exempt from the consequences of occupational stress, showing problems such as dissatisfaction with work, burnout syndrome, and absenteeism ${ }^{(1,3,6-7)}$.

The practice of the nursing profession occurs mostly in hospital environments, demanding more involvement from the professional. Inpatients suffer considerably because of this situation. Being away from home, from work, and the lack of information about what is happening and what will happen to him/ her causes an intense emotional overload. It is up to nurses to provide him/her with the necessary comforts for recovery. Therefore, nursing is in constant contact with suffering, pain, desperation, irritability, and other reactions that patients may have because of their situation $^{(1,5-15)}$.
Within the hospital context, the intensive care units have already been the focus of several research studies related to nurses' stress. It is known that this sector in the hospital is tasked with caring for patients in an acute or critical state, but within the possibility of recovery; patients who require specialized, permanent medical and nursing care; patients subject to having unstable vital functions, who need the support of special equipment for treatment and diagnosis $^{(1,6,9,11)}$.

Therefore, the nursing professionals who work in such units are expected to have accurate scientific knowledge, to be aware of technical and technological changes, and to be highly specialized. This may be the reason why the first stress-related investigations on nurses, which took place in the 1960s, have mostly been done in intensive care units ${ }^{(1-2,4,9)}$.

Investigation of factors that stress the nurse in intensive care units are related to a confined working environment, artificial lighting, air conditioning, workplace architecture, constant demands from superiors, highly-demanding routines, lack of human resources, noisy and sophisticated equipment, and the possibility of death and pain. Such factors may cause inappropriate working conditions for the nursing activity, causing mood swings, allergies, headaches, and anxiety, among other symptoms ${ }^{(4,8-9)}$.

Authors tend to agree that nursing is, among other occupations, quite stressful. When treating critical patients, it is even considered wearisome, and being a part of such day-to-day routine makes the nurse susceptible to stress ${ }^{(10-15)}$.

In face of these inquiries, the present study was performed, aiming to identify the presence of stress in nurses who work in intensive care units, to identify the stress agents and the symptoms associated to the nurse's perception, and to assess the correlation between the presence of stress, sources of stress and symptoms shown by nurses.

\section{METHODS}

This is a cross-sectional study, where the information about the factors of exposure (scores of stress sources) and the effects (scores of stress symptoms) were collected simultaneously, with a selfadministrated questionnaire.

The study was performed at the Israelite Hospital Albert Einstein, a 400-bed private hospital in 
the city of São Paulo. In this hospital, 140 of the beds are in intensive care units, divided in Adult Intensive Care Unit, Pediatric Intensive Care Unit, and Neonatal Intensive Care Unit. The units are similar in organizational structure and working processes. Seventy-five nurses who have been employed for over 6 months in the aforementioned units were interviewed.

The research project was analyzed and approved by the Research Ethics Committee of the Albert Einstein Israelite Institute of Research and the Ethics Committee of the Federal University of São Paulo.

The nurses were invited to participate in the study after being informed of the objectives and goals through e-mail and personal contact between the investigator and the team. Participation was voluntary and documented with a consent form attached to the questionnaire.

The original version of the self-administrated questionnaire was used in previous studies with a group of managers in a company. Later, it was adapted to a group of nurses with management duties and used in a research on nurses' management functions. Twenty-one nurses were assessed in a pilot study, and after the data had been analyzed, the questionnaire was enhanced to meet the objectives of the present study. Finally, it was re-sent to the Research Ethics Committee of the Albert Einstein Israelite Institute ${ }^{(4-6)}$

The questionnaire was divided in two parts. The first part covered the identification of the nurse (age, marital status, gender, number of children, working sector, length of time in the profession and length of time employed in the hospital) and the investigation of aspects related to working conditions (job satisfaction, willingness to change jobs and expectations towards the profession) ${ }^{(4)}$.

The second part was subdivided in two sections. Section I covered activities and possible sources of stress, separated by score: function conflicts (questions addressing the nurse's role regarding obligations, goals, conflicts with hierarchical subordinates and superiors); work overload (questions about long hours, taking work to be done at home, having to perform several tasks); interpersonal relations (approaching concerns in keeping satisfactory professional relations, disputes for positions with co-workers, conflicts with patients and family members); personal management (approaching situations such as personnel evaluation, negotiating with peers in the company, negotiation with the team, assuming a management position); critical situations (related to taking criticism, disputes for positions, overcoming resistance to change, conflicts between personal and professional life and dealing with death, odors, and noise on a daily basis) ${ }^{(4)}$.

Section II covered symptoms perceived by nurses, subdivided into cardiovascular (tachycardia, hypertension, arrhythmias, dizziness, cold sweat and headaches); digestive disorders (lack of appetite, flatulence, nausea, vomiting, gastritis, ulcers, diarrhea and constipation); immune system disorders (chills, colds, constant flu, hyperthermia and infectious diseases); sleep and rest disorders (insomnia, nightmares and sleep cycle disorders); musculoskeletal disorders (aching joints, lumbar, nape, cramps and muscle spasms); changes in the menstrual cycle (irregular cycles, pain when menstruating, amenorrhea and unending hemorrhages); social habits (using tobacco, alcoholic beverages, sleeping pills and antidepressants) ${ }^{(4)}$.

The answer for each question was scored from zero to four according to the Likert scale, with zero meaning absence of stress or symptoms, and four meaning maximum stress and symptoms perceived in high intensity.

\section{STATISTICAL ANALYSIS}

To evaluate whether the identified symptoms were associated to sources of stress and to working conditions, the Pearson correlation coefficients were calculated and general linear models were adjusted.

The answer variables in these models were each of the symptom scores (cardiovascular, digestive, immune response, muscle pain, sleep disorders and social habits).

The explanative variables were the stress source scores (function conflicts, work overload, critical situations and problems with professional relations), related to the length of time in the profession, length of time as an employee in the hospital, age, and working shift.

The model applied in different distributions for the variable response was the Normal model, which produced the best effect for the analysis of the variables. 
Given the large number of explanative variables in each model, a stepwise forward method was used, where the explanative variables were inserted individually in the model, from most important to least important. The Pearson correlation coefficient was used to determine the importance of each variable in the score explanation- the higher the coefficient, the more important the variable. At every step of the process, a new variable was tested and it would either remain in the model or not. For a variable to remain in the model, it was necessary for its coefficient to be different from zero (assessed with the Wald test), and the model with this variable should be significantly better than the model without this variable (evaluated with the $\mathrm{F}$ test).

\section{RESULTS AND DISCUSSION}

Results are presented according to the sequence of the questionnaire proposed for this investigation. According to the description of the population characteristics, most were women $(90.7 \%)$, and most were single $(60.0 \%)$.

Countless studies on the same topic show a predominance of women. Some of them report the fact of women having to balance home and work duties as a source of stress, causing a double shift, which may wear away their marital and social life, causing depression, fatigue, and work dissatisfaction ${ }^{(1,3-7)}$.

As for the nurses' assignments, most belong to the adult intensive care unit $(78.70 \%)$, with pediatric intensive care unit coming second $(14.7 \%)$ and neonatal intensive care unit coming last (6.7\%). Regarding working shifts, most belong to the night shift (53.3\%) and have a postgraduate degree (93.3\%).

Although the research occurred in three different intensive care sectors, with patients classified by age and complexity of disease and care, a correlation among the different characteristics of the sectors was not observed, making the experiences of the nurses similar in the adult, pediatric, and neonatal intensive care units.

The results observed in this study do not show impact on the stress levels in different working shifts. However, investigations on this topic show that individual differences, situations at work and changes in sleep and wake may be responsible for the nurse's stress, with one of the agents being the alternating working shifts - particularly the night shift ${ }^{(16)}$.
According to data from investigations on nurses' stress, post-graduation may be a positive factor for the professional, since it usually leads to seeking out new projects, increasing self-esteem and contributing for a better performance and security to face the stress factors ${ }^{(7,17)}$.

Characteristics related to age, number of children, length of time working in the hospital and length of time in the career presented in descriptive measurements identified a majority between 23 and 47 years of age $(S D \pm 5.8)$. The number of children averages at $0.5(S D \pm 0.9)$, and length of time working in the hospital and career were 5.8 years (SD \pm 5.2 ) and 5.1 years (SD \pm 5.1 ), respectively.

Such data shows that a large amount of the nurses who belong to intensive care units has been working in the institution since graduation. This fact, according to literature, may help the professional to reduce the feelings of stress, with a higher experience and identification with the workplace probably causing a lower negative stress impact ${ }^{(3-6,18)}$.

Marital status and number of children were not found to be relevant as a stress source, neither in literature nor in this study ${ }^{(1,3-15)}$.

As for the relation between the analyses of information regarding working conditions, such as questions referring to the nurse's satisfaction with his/ her activity in the intensive care unit, there was a prevalence of professionals who were dissatisfied with their work. Table 1 shows the distribution of frequency of nurses who reported being dissatisfied with their work.

Table 1 - Distribution of frequency of nurses according to the responses about dissatisfaction with their work

\begin{tabular}{ccc}
\hline \multicolumn{1}{c}{ Variables } & Frequency & Percentile \\
\hline Satisfied with their work & 31.0 & 41.3 \\
Dissatisfied with their work & 44.0 & 58.6 \\
\hline Total & $\mathbf{7 5 . 0}$ & $\mathbf{1 0 0 . 0}$ \\
\hline
\end{tabular}

It was observed that, when questions referred to stress levels, following the sequence of the questionnaire, there was a correlation between the dissatisfaction score and the sources of stress.

In this study, the correlation found between these variables was statistically significant, i.e., the nurses who report being dissatisfied with their work show higher levels of stress when facing factors related to the nursing functions in intensive care units, identified as sources of stress in this study. 
Some studies have mentioned that the manifestations of dissatisfaction with work suggest a scenario that is prone to aggravating stress, causing a state of burnout and exhaustion associated to high levels of absenteeism due to disease and depression ${ }^{(3-6,16-18)}$.

Table 2 presents the coefficient of the regression model during the stepwise forward process.

The independent variables were parts of each identification score and stress agents inserted in the logistic model, increasing according to their statistical significance, and remaining in the model if they were still significant $(* p<20)$. A stepwise forward procedure was adopted, and it was possible to evaluate the independent impact of each type of score on the individual's perception.

At the end, the variables that remained in the model were the scores of dissatisfaction with work and critical situations, independent of the length of time in the profession, hospital, age and working shift.

Table 2 - Coefficient of the regression model during the step forward procedure

\begin{tabular}{|c|c|c|c|c|c|}
\hline \multirow{2}{*}{ Step } & \multicolumn{5}{|c|}{ Model } \\
\hline & 1 & 2 & 3 & 4 & 5 \\
\hline Score of dissatisfaction with work & $10.9^{*}$ & $8.6^{*}$ & $8.4^{*}$ & $8.6^{*}$ & $9.0^{*}$ \\
\hline Critical situations score & & $0.7^{*}$ & $0.4^{*}$ & $0.6^{*}$ & $0.8^{*}$ \\
\hline Conflict of functions score & & & $0.4^{*}$ & & \\
\hline Work overload score & & & & $0.4^{*}$ & \\
\hline Interpersonal relations score & & & & & $0.4^{*}$ \\
\hline \multicolumn{6}{|l|}{ Personal management score } \\
\hline \multicolumn{6}{|l|}{ Gender score } \\
\hline \multicolumn{6}{|l|}{ Time at work (years) } \\
\hline \multicolumn{6}{|l|}{ Workplace } \\
\hline \multicolumn{6}{|l|}{ Time at the hospital (years) } \\
\hline \multicolumn{6}{|l|}{ Number of children } \\
\hline \multicolumn{6}{|l|}{ Age } \\
\hline \multicolumn{6}{|l|}{ Working shift } \\
\hline \multicolumn{6}{|l|}{ Marital status } \\
\hline $\mathrm{R}^{2}$ & 0.26 & 0.33 & 0.35 & 0.33 & 0.34 \\
\hline$p$ & 0.00 & 0.00 & 0.21 & 0.96 & 0.56 \\
\hline
\end{tabular}

Several authors point out that the continuing presence of dissatisfaction with the nurse's work is associated with his/her activity, and the functions that they perform daily become stress sources, interfering in their health and quality of life $e^{(1,3,7,15)}$.

According to the symptoms score related to the stress level, there is a correlation between the score of dissatisfaction with work and the scores of stress sources, with a predominance of the critical situations score. Such situations cover issues such as meetings with superiors, taking criticism from superiors, taking criticism from subordinates, facing crisis at home or in the company, feeling alone when making decisions, lack of power and influence, fear of losing the job, performing tasks above or below their level, nauseating odors, mistakes made, death of patients, and feeling undervalued.

Table 3 presents the final linear regression model for the symptoms score. The variables that remained in the model were dissatisfaction with work and the critical situations score. This does not mean that other variables are not associated to the symptoms score, but that, when in presence of the dissatisfaction with work variable and critical situations, they do not present any additional contribution to explain the symptoms score.

According to the model of Table 3, the nurses who reported dissatisfaction with work scored 8.34 more points in the symptoms score than those who were satisfied with their work. Moreover, each point scored in critical situations corresponds to an increase of 0.62 point in the symptoms score.

Table 3 - Final model of linear regression for the symptoms score

\begin{tabular}{lccc}
\hline \multicolumn{1}{c}{ Explanative variable } & Coefficient & Standard Error & $\mathbf{P}$ \\
\hline Dissatisfaction with work & 0.34 & 2.17 & 0.0003 \\
Critical situations score & 0.62 & 0.23 & 0.0093 \\
Intercept & 7.96 & 8.67 & 0.3621 \\
\hline
\end{tabular}

$p<0.05 *$

Studies that evaluated occupational stress suggest a response that depends on the individual capacity of interpreting, assessing, and elaborating coping strategies when facing a stressful event, along with cognitive and physiological components, depending on the frequency and magnitude of the events, causing a chain of organic reactions that may trigger the onset of diseases, depression and fatigue ${ }^{(10-13)}$.

The information in this study seems to be in consonance with the findings of the aforementioned authors. Dissatisfaction with work, added to situations considered critical by the professional may lead to stress, showing symptoms related to the triggering of organic factors that, if not kept under control, may cause serious diseases and discontentment with the profession $^{(1-15)}$.

In this study, the symptoms that showed a higher correlation to the stress levels were cardiovascular symptoms, digestive disorders and musculoskeletal disorders. Table 4 presents the descriptive measurements for the symptoms score, 
i.e., the nurses who had high stress levels had more complaints of cardiovascular, digestive and musculoskeletal symptoms.

Table 4 - Descriptive measurements for the symptoms scores

\begin{tabular}{lccccc}
\hline \multicolumn{1}{c}{ Variables } & Average & $\begin{array}{c}\text { Standard } \\
\text { Deviation }\end{array}$ & Minimum & Median & Maximum \\
\hline Cardiovascular & 3 & 1 & 0 & 2 & 4 \\
Digestive & 3 & 1 & 0 & 2 & 4 \\
Immune system & 1 & 1 & 0 & 1 & 4 \\
Sleep and rest & 1 & 1 & 0 & 1 & 4 \\
Musculoskeletal & 3 & 1 & 1 & 2 & 4 \\
Menstrual cycle & 1 & 1 & 0 & 1 & 4 \\
Social habits & 1 & 1 & 0 & 1 & 4 \\
\hline
\end{tabular}

The associations between stress and cardiovascular, digestive and musculoskeletal disorders are involved in the neuronal activation chain. When exposure to stress sources causes a prolonged response to stress, there is an increased secretion of catecholamines and cortisol, leading to organic changes with the manifestation of symptoms. Other symptoms, according to literature, are associated to the stage of exhaustion, when the organism does not return to homeostasis and there is an overload in the organs and systems resulting in diseases. These were not observed in this study ${ }^{(2,6-8)}$.

According to other authors, the aforementioned stress symptoms are associated to several situations, such as regulations, determinations by superiors, administrative issues, affective bonds and tensions related to keeping the job, making it impossible to manifest feelings and developing demonstrations of dissatisfaction with the $\operatorname{activity}^{(1,3,13,15,18)}$.

The data show that there was no statistical significance in the correlation between the presence of stress and its causes with social habits.

According to literature, such habits may be related to changes in social and psychological structure of the nurse in face of his/her involvement with the profession, having to deal with pain and suffering of patients daily. This situation may provide different and more mature perspectives towards social habits. Since it was not possible to conjecture on these data, it should be the object of a further specific scientific investigation $^{(3-18)}$.

Other aspects deserving reflection are those related to the length of time in the career and the length of time working for the hospital in this study. According to the results, it showed a negative correlation with the levels of stress associated to stress sources and symptoms reported by the nurses. Table 5 presents the correlation matrix for the symptoms scores, variables of identification and length of time in the career, length of time at the hospital and age.

Table 5 - Correlation matrix for the symptoms scores and length of time in the career (in years), length of time at the hospital (in years) and age

\begin{tabular}{lc}
\hline \multicolumn{1}{c}{ Variables } & Symptoms score \\
\hline Age (years) & -0.06 \\
Length of time at the hospital & -0.20 \\
Length of time in the career & -0.24 \\
\hline
\end{tabular}

$p<0.05^{*}$

Some authors have shown that stress levels are inversely correlated to time, i.e., the higher the professional or personal experience, the lower the stress factors. For these authors, time offers subsidies for the conformity and better evaluation of the professional activity, mediating the negative impact of stress at the workplace ${ }^{(18)}$.

As stated before, there was no correlation among stress levels with apparent symptoms with the workplace, marital status and number of children. However, the scores of length of time in the career and length of time at the hospital have shown, even if discreetly, an inverse correlation with the stress levels with apparent symptoms, reported by the nurses.

According to the data assessment, the stress agents relate to the state of satisfaction with the professional activity. The generating circumstances influence health, resulting in symptoms.

Literature has shown that inefficient coping causes inappropriate strategies, bringing about both formal and informal communication difficulties in the workplace, without enough time to deal with peers in the company. There is also inefficiency in the function, associated to tiredness and lack of motivation, causing harm to health, such as changes in blood pressure, headache, palpitations, digestive disorders, immune disorders interfering on the presence and duration of symptoms, and vulnerability to disease ${ }^{(6-9)}$.

Other studies have investigated nurses' stress with scales to determine presence, causes and symptoms. They verified that the major cause of stress is related to dissatisfaction with work, leading to emotional exhaustion and lack of personalization in the activity, related to aspects of the work and 
environment, relations with the team and peers in the company, pressure from superiors and conflicts between personal and professional life. In this context, the work environment is perceived as a threat to the individual, reflecting on the personal and professional plane, provoking demands that are higher than its

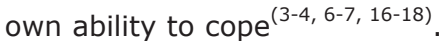

The continuing presence of the nurse's dissatisfaction with his/her professional activity, associated to stress agents and the symptoms score suggest a possible burnout outcome, featured as a higher degree of dissatisfaction interfering with his/ her health and quality of life.

Although the data present lower scores according to time and age, the effect is still the feeling of weariness towards the profession, with the risk of falling ill and jeopardizing the forms of stress control.

As for the stress agents, the most frequent in this study were critical situations, which involve taking criticism, crisis between superiors and subordinates, difficulties to face situations demanding confrontations with superiors, co-workers and subordinates, feeling inferior to the function requirements and difficulties when caring for patients with serious problems.

\section{REFERENCES}

1. Bianchi ERF. Enfermeiro hospitalar e o stress. Rev Esc Enferm USP 2000; 34(4):390-4.

2. Seyle H. The physiology and pathology of exposure to stress. Canadá: Acta, INC; 1956.

3. Bianchi ERF. Stress em Enfermagem: Análise da Atuação do Enfermeiro em Centro Cirúrgico. [Dissertação]. São Paulo (SP): Escola de Enfermagem/USP; 1990.

4. Lautert L, Chaves EHB, Moura GSS. O stress na atividade gerencial do enfermeiro. Revista Panam Salud Publica 1999; 6(6): $415-25$

5. Car MR. Problema de enfermagem da esfera física em pacientes hospitalizados: caracterização por unidades de internação, cuidado semi-intensivo e tratamento intensivo [dissertação]. São Paulo: Escola de Enfermagem/USP; 1986. 6. Cavalheiro AM, Ruggiero C, Garcia A, Higashi P, Melin SA. Níveis de stress em enfermeiros com atuação em centro de terapia intensiva em hospital particular da grande São Paulo, [Monografia]. São Paulo (SP): Pontifícia Universidade Católica de Campinas; 2003.

7. Sanguiolliano LA. Stress dos enfermeiros em um hospital privado e as conseqüências no seu estado de saúde, [Dissertação]. São Paulo (SP): Escola de Enfermagem/USP; 2004.

8. Spindola T. O CTI sob a Ótica da Enfermagem. Rev Enfermagem UERJ 1993; (2):56-67.
In short, this study presented the variables dissatisfaction with work, critical situation score, symptoms related to cardiovascular, digestive and musculoskeletal changes as sources of stress, directly correlated with the levels of stress.

\section{CONCLUSION}

The analysis of the results in this study about the presence of stress in nurses working in intensive care units reached the following conclusions:

Regarding dissatisfaction with work, a correlation between the levels of stress with repercussions in health was found, with manifestations of cardiovascular stress, digestive disorders and musculoskeletal disorders.

There was an evident correspondence with time, probably due to maturity and experiences, resulting in a higher awareness of his/her actions and finding mechanisms to cope with stress.

The study indicated that there was a relation between the stress sources identified by the questionnaire of critical situations with the levels of stress and general dissatisfaction with work.

9. Tesck, ECB. Convivência continua com stress: vida e trabalho de enfermeiros nas unidades de terapia intensiva. [Dissertação]. Rio de Janeiro (RJ): Escola de Enfermagem Ana Néri/UFRJ; 1982.

10. Mendes R. Patologia do Trabalho. $8^{\mathrm{a}}$ ed. Rio de Janeiro: Atheneu; 1995.

11. Mauro MYC. Riscos Ocupacionais em Saúde. Revista Enfermagem Científica 1991; 3:77-80.

12. Boemer MR, Sampaio MA. O exercício da enfermagem em sua dimensão bioética. Rev Latino- am Enfermagem 1997 abril; 5(2):33-8.

13. Stacciarini JMR, Trócoli BT. O stress na atividade ocupacional do enfermeiro. Rev Latino-am Enfermagem 2001; 9(2):17-25. 14. Gomes AM. Enfermagem na unidade de terapia intensiva. São Paulo: EPU; 1988.

15. Peiró JM. Desencadeamento Del estrés laboral. Madrid: Eudema; 1993.

16. Chaves EC. Stress e trabalho do enfermeiro: a influencia de características individuais no ajustamento e tolerância ao turno noturno [dissertação]. São Paulo: Instituto de Psicologia/USP; 1994.

17. Guido LA. Stress e coping entre enfermeiros de centro cirúrgico e recuperação anestésica. [dissertação]. São Paulo: Escola de Enfermagem/USP; 2003.

18. Ferreira FG. Desvendando o stress da equipe de enfermagem em terapia intensiva. [dissertação]. São Paulo: Escola de Enfermagem/USP; 1998. 